\title{
Genotypic intragroup variance and hoarding behaviour in honeybees (Apis mellifera L.)
}

\author{
R.F.A. Moritz 1 and E. Hillesheim 2 \\ 1 Bayerische Landesanstalt für Bienenzucht, Burgbergstrasse 70, D-8520 Erlangen, FRG \\ 2 Zoologisches Institut, Universität Basel, Rheinsprung 9, CH-4051 Basel, Switzerland
}

(received 31 October 1988, accepted 18 August 1989)

\begin{abstract}
Summary - Sugar consumption and hoarding behaviour of groups of honeybee workers were measured. Groups with different genotypic intragroup variabilities were tested to detect a relationship between intragroup variance and cooperative group efficiency. A significant correlation was found between genotypic variance and with both sugar consumption and hoarding behaviour. High intragroup variance caused a low hoarding performance, a high food consumption and a low sugar concentration in the stored sugar syrup. It is concluded that the genotypic variance of a group has a strong influence on the expression of social behaviour in groups.
\end{abstract}

Apis mellifera - hoarding behaviour - genetic variation - genetic marker

\section{INTRODUCTION}

The efficiency of honeybee colonies (Apis mellifera L.) strongly depends on the cooperative behaviour of worker bees. Several mechanisms determine how the individual honeybee contributes to cooperative group behaviour in the colony. The best understood system is age-dependent polyethism (Rösch, 1925, 1927; Lindauer, 1952). However, division of labour is not exclusively determined by age (Rösch, 1930). Honeybee colonies can quickly respond to environmental changes by shifting workers from one behavioural task to another (Sakagami, 1953).
Beside age and environmental effects, genetic variability also accounts for division of labour. Moritz and Hillesheim (1985) found a large genetic variance for egg laying and nonreproductive workers. Recent studies (Calderone and Page, 1988; Frumhoff and Baker, 1988; Robinson and Page, 1988) gave further evidence that genotypic variability among the workers is an important factor to establish division of labour in honeybee colonies. The polyandrous mating behaviour of the honeybee queen (Adams et al., 1977) results in a large genotypic variance among the workers in natural colonies. If cooperative group behaviour depends on the degree of genotypic variance in a colo- 
ny, this would be an additional model for the evolution of polyandry to those suggested by Crozier and Page (1985).

There have been few reports on the effect on group behaviour of combining genetically different workers. Winston and Katz (1982) introduced workers of a race with "late starting age of foraging" into a colony with workers which started foraging early. The host colony determined the phenotype of the introduced workers, which started foraging early in their life-span. This is a typical case of non-linear interactions between workers - such that one behavioural type (early foraging) determines the phenotype of the other. Another mode of non-additive genotype interactions in honeybees was found by Moritz and Southwick (1987). They reported a maximal alarm reaction in worker groups with a high genotypic variance. Additive (linear) interactions were found when mixed groups of high- and low-line workers $(1: 1)$ showed behaviour intermediate between worker groups of the two pure lines for brood care, comb construction and hoarding (Hillesheim et al., 1988). The above examples show that additive and non-additive interactions between workers are important for the expression of group phenotypes (see Moritz, 1988a). In the present paper, we determine the effect of genotypic intragroup variance on classical social behaviour of small groups of workers. We used phenotypic mutant markers to control the genotypic variance and to test its effect on hoarding behaviour.

\section{MATERIALS AND METHODS}

\section{Mutant markers}

A honeybee queen (Apis mellifera carnica Poll.), homozygous at 3 non-linked loci $(\mathrm{cd}=$ cordo- van, $i^{\mathrm{U}}=$ ivory (umber allele), $\mathrm{di}=$ diminutive) was instrumentally inseminated with a set of 4 different drones. Each drone carried a different combination of the three markers $(+,+,+; \mathrm{cd},+$, $+; \mathrm{cd}, \mathrm{i}^{\mathrm{u}},+; \mathrm{cd},+, \mathrm{di} ;+=$ wild type). Each offspring worker had the same phenotype as its father. Supersib and halfsib workers could be easily identified. Because the drones and the queen were related, the offspring workers were both inbred $(F=0.28)$ and more closely related (supersibs : $r=0.78$; halfsibs: $r=0.32$ ) than under outbreeding conditions (Fig. 1).

\section{Bio-assay}

A sealed brood of the inseminated queen was placed in an incubator $\left(34^{\circ} \mathrm{C} ; 70 \%\right.$ rh.). Newly emerged workers were collected daily and

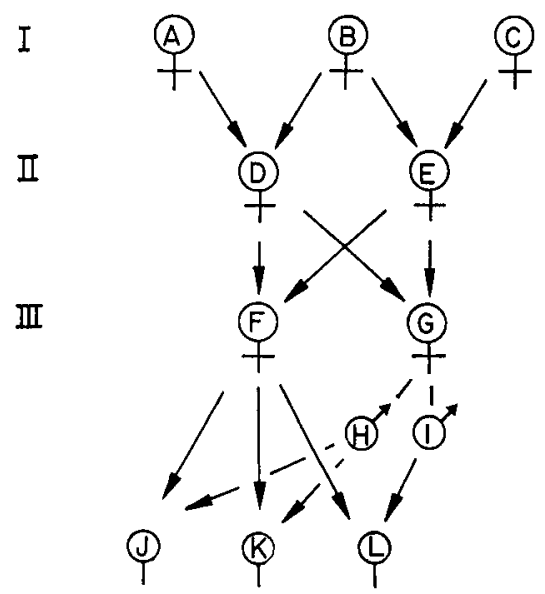

Fig. 1. Pedigree of the marker line used in the experiments. All queens, except queen $F$, were inseminated with a large mixed semen pool of the corresponding drone mother. Therefore, drone mothers are treated as diploid organisms in the pedigree. Queen $F$, the experimental queen, was inseminated with semen from 4 brother drones of queen $G$ (for clarity only 2 are shown). Worker offspring from queen $F$ were used in the experiments. Due to inbreeding, the workers of the same patriline were related by $r=0.78(\mathrm{~J}$ and $\mathrm{K})$, and workers from different patrilines were related by $r=0.32$ ( $K$ and $L$ ). All workers had an inbreeding coefficient of $F=0.28$. 
groups of 60 workers (test groups) were placed in small screened cages $(10 \times 5.5 \times 12.5 \mathrm{~cm})$. The genotypic composition of these groups varied such that they consisted of $1,2,3$ or 4 patrilines at equal ratios (Table I). The bees were fed ad libitum with water and sugar syrup (40\%) via gravity feeders and with pollen (in a tray). The gravity feeders were exchanged every second day; pollen was renewed in daily intervals.

The amount of syrup stored in the comb and the amount taken from the feeder, the day of initial hoarding, and the quantity of actual sugar stored in the comb were recorded. The latter was evaluated by the volume of stored syrup (estimated via the number of filled cells), and sugar concentration (measured in a refractometer) at the end of the test period. The metabolic sugar consumption of the group was estimated by subtracting the amount stored from the total sugar taken from the feeder.

\section{RESULTS}

\section{Sugar concentration}

The overall mean sugar concentration in the stored syrup $(64.9 \pm 1.34 \%)$ was lower than in cells artificially filled with syrup and left without bees under the same conditions $(79.2 \pm 1.2)$. There was a significant correlation $(r=-0.34, P<0.05)$ between the day of initial hoarding and the final sugar concentration.

There was no significant difference among the patrilines for final sugar concentration in the pure groups $(F=1.15$, n.s.; Table II), although variance among the different types of mixed groups was

Table l. Composition of worker groups tested.

No. of

patrilines in group $r$ genotype of patrilines

No. of

groups tested
1

2

0.55

0.47

0.44

$\begin{array}{ll}+++ & 6 \\ c d++ & 5 \\ c d i u+ & 3 \\ c d+d i & 5 \\ & \\ +++/ c d++ & 7 \\ +++/ c d i^{u}+ & 3 \\ +++/ c d+d i & 4 \\ c d++/ c d+d i & 5 \\ c d++/ c d i u+ & 2 \\ c d i+/ c d+d i & 2 \\ & \\ +++/ c d++/ c d i u+ & 4 \\ +++/ c d++/ c d+d i & 4 \\ +++/ c d i u+/ c d+d i & 3 \\ c d++/ c d i u+/ c d+d i & \end{array}$

$+++/ c d++/ c d i^{u}+/ c d+d i$

\section{6}

3

5

3

4

5

2

2

4

4

9

\footnotetext{
* The number of patrilines participating in the composition of a test group, the average individual relationship $r$ (Moritz, 1988b) and the genotypes of the siring drones are listed. Each group consisted of 60 workers and each patriline was equally represented in the mixed groups.
} 
Table II. Hoarding data 'mean \pm SE) of test groups of 60 workers of single patrilines.

\begin{tabular}{ccccc}
\hline Genotype & \multicolumn{3}{c}{ Sugar } & $\begin{array}{c}\text { First } \\
\text { day of } \\
\text { hoarding }\end{array}$ \\
\cline { 2 - 4 } & Conc. (\%) & Metabolized $(g)$ & Stored $(g)$ & \\
\hline & & & & \\
+++ & $73.8 \pm 1.5$ & $5.78 \pm 0.36$ & $0.32 \pm 0.39$ & $3.8 \pm 0.9$ \\
cd ++ & $72.2 \pm 3.1$ & $4.63 \pm 0.26$ & $1.35 \pm 0.44$ & $2.6 \pm 0.2$ \\
cd + di & $67.5 \pm 3.9$ & $4.77 \pm 0.31$ & $0.67 \pm 0.65$ & $2.2 \pm 0.5$ \\
cd iu + & $64.3 \pm 9.3$ & $6.07 \pm 0.40$ & $0.77 \pm 1.25$ & $2.2 \pm 0.9$ \\
\hline
\end{tabular}

significant $(F=6.66, P<0.001$; Table III). With increasing number of patrilines in the group, the concentration significantly decreased (Spearman's rank test : $r_{\mathrm{s}}=-0.51$, $P<0.001$; Fig. 2c) .

\section{First day of hoarding}

There was considerable variance for the first day of hoarding among the groups tested. Some started the first day, whereas others did not start before day 7 . Nevertheless, an ANOVA showed that the group composition had no significant effect on this character (Tables II and III).

\section{Metabolized sugar}

A homogeneity test on the amount of metabolized sugar revealed significant differences among the patrilines (F $=3.34, P<$ 0.05 ; Table II) with 2 high and 2 low metabolic types. With this information, expectation values were calculated for the genotypically mixed groups, assuming additivity. Based on this model there should be no correlation between genotypic variance and metabolized sugar. Figure 2 , however, clearly shows that the ob- served data drastically differ from those expected. There was a significant correlation between the number of patrilines in a group and the metabolic sugar consumption $\left(r_{\mathrm{s}}=0.25, P<0.05\right.$, Fig. $\left.2 \mathrm{~b}\right)$.

\section{Stored sugar}

Pure groups of all 4 patrilines showed similar hoarding behaviour (ANOVA, $F=2.27$, n.s., Table II). The 4 classes of genotypic variance in the groups, however, caused a significant variation in the data set $(F=$ 3.77, $P<0.05$, Table III). Also Spearman's rank correlation reveals a highly significant negative correlation $\left(r_{\mathrm{s}}=0.4, P<0.01\right)$ between the number of patrilines in the group and the amount of hoarded syrup. Groups with a large genotypic variance were less efficient in hoarding than pure groups of a single patriline (Fig. 2a).

\section{DISCUSSION}

Although the workers in our tests were closely related, we could well relate the metabolic sugar consumption of workers to certain patrilines. Since the genetic mark- 


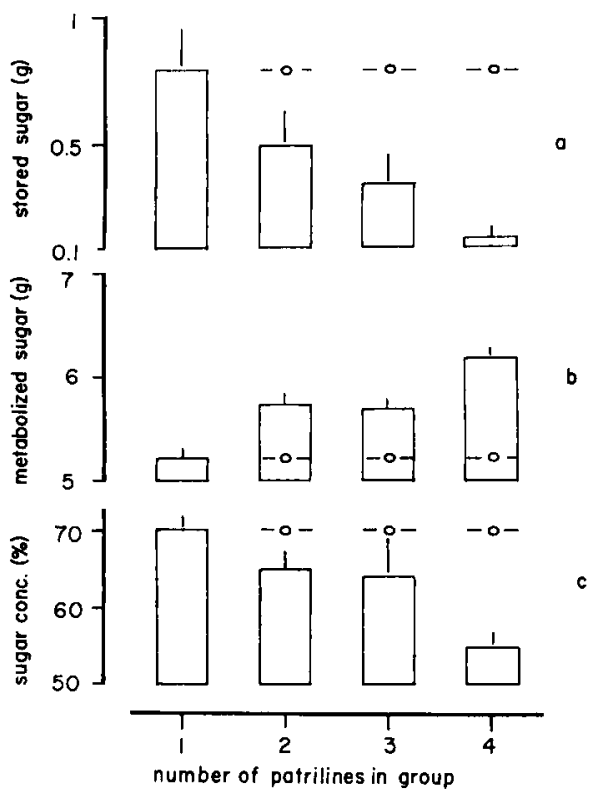

Fig. 2. Correlation between the number of patrilines per group ( $x$-axis) and: $a$. the amount of stored sugar $(g)$; $b$. the metabolic sugar consumption (g); c. the final sugar concentration of the stores (\%); 0 - = expected mean values for additive genotype interactions; data are presented as mean \pm SE.

ers do not affect the metabolic rates of workers (Moritz, 1988b), it seems reasonable to assume that genes other than the marker loci caused these differences. Sug- ar consumption was not linked to the amount of sugar stored in the comb, which was not significantly different among the 4 patrilines. Thus, although there was a difference in the amount of sugar taken from the feeder, which is the classical parameter for hoarding behaviour tests (Kulincevic and Rothenbuhler, 1973), the stored food was similar for all pure test groups of single patrilines. This shows that the syrup reduction in the feeder is a poor parameter for hoarding, because it does not necessarily reflect the amount of syrup actually stored. Since hoarding behaviour has been claimed to correlate with honey production of colonies (Kulincevic et al., 1974, Milne, 1980 ), it seems to be important to discriminate carefully between the syrup taken from the feeder and the stored syrup (Free and Williams, 1972).

Although we found low absolute amounts of hoarded syrup in our experiment, they were still in the range of prior studies $(50 \%$ of that given by Rinderer (1981), and Rinderer and Baxter (1980); $25 \%$ of that given by Free and Williams (1972)). Since we inseminated the queen with closely related drones, the low variance among the 4 patrilines is not surprising. The use of inbred workers may be the main reason for the low hoarding found in this study. Brückner (1980) found that inbreeding seriously affected hoarding behaviour of workers.

Table III. Hoarding data (mean \pm SE) depending on the number of patrilines in each test group.

\begin{tabular}{lllll}
\hline $\begin{array}{l}\text { No. of } \\
\text { patrilines } \\
\text { in group }\end{array}$ & Conc. (\%) & Metabolized $(g)$ & Sugar & $\begin{array}{l}\text { First } \\
\text { day of } \\
\text { hoarding }\end{array}$ \\
\cline { 2 - 5 } & & & & \\
\hline 1 & $71.2 \pm 1.7$ & $5.19 \pm 0.23$ & $0.79 \pm 0.17$ & $2.9 \pm 0.4$ \\
2 & $64.8 \pm 1.8$ & $5.69 \pm 0.31$ & $0.50 \pm 0.13$ & $3.1 \pm 0.3$ \\
3 & $64.2 \pm 4.4$ & $5.61 \pm 0.20$ & $0.25 \pm 0.11$ & $3.2 \pm 0.2$ \\
4 & $54.1 \pm 6.7$ & $6.17 \pm 0.18$ & $0.12 \pm 0.03$ & $3.2 \pm 0.3$ \\
\hline
\end{tabular}


The correlation between final sugar concentration in the stores and the onset of hoarding is a physical rather than a biological phenomenon. Because of water evaporation the sugar concentration increases over storage time. Cells artificially filled with $100 \mu \mathrm{l}$ syrup (40\%) had an average sugar concentration of $79.2 \%$ after 6 days in cages with no bees. Since there was no significant difference in the onset of hoarding for all tested groups, the reduced sugar concentration in the mixed groups is not a result of this time effect. Therefore, the differences in sugar concentration found in this study, most likely result from an efficient behavioural evaporation system of the workers (Lindauer, 1952).

Although the amount of hoarded syrup was very similar for the 4 patrilines, the genotypic mixing had significant effects on hoarding behaviour. The mixed groups increased sugar consumption and decreased stores. Apparently, each addition of a patriline to a test group has a negative effect on hoarding. Thus, the resulting group phenotype did not resemble the expected "average" behaviour (additivity) but revealed strong non-linear interactions among genotypes. Non-linear interactions between genotypes on the expression of group behaviour have been reported several times (Trump et al., 1964; Moritz and Southwick, 1987; Winston and Katz, 1982). Our case is the first report in which genotypic variability has had a negative effect on group performance.

Our results are in accord with the increased metabolic activity of genotypically mixed groups in alarm reactions (Moritz and Southwick, 1987). In our hoarding tests, genotypically mixed groups had a higher sugar consumption which may reflect an increased metabolic rate. The actual biological mechanism behind this phenomenon remains unclear. Nevertheless, it is obvious that such non-additive interactions make predictions on the selectability of social traits highly complex (Moritz, $1986,1988 a)$. If the genotypic variance of a group, rather than the genetic value of individuals, determines the expression of a particular genotype, it would be extremely difficult to perform any selection.

\section{CONCLUSIONS}

In the light of the evolution of polyandry, our results may look surprising. Apparently the performance of the groups was reduced and not increased under genotypic variability. However, this observation does not necessarily rule out that genotypic variability of honeybee colonies is a selective motor for polyandry in natural selection. Hoarding behaviour as tested in our assay could just be not very important for the fitness of colonies. Certainly, more information is needed to get a clearer picture of the interactions between individual group members and the construction of group phenotypes. Analysis of group traits more closely related to colony fitness will reveal the importance of genotypic variance for the evolution of polyandry. Only when we understand the genetics of conflict and cooperation in social groups will we be able to gain insight into the basic principles of natural selection in honeybee populations.

\section{ACKNOWLEDGMENTS}

We wisk to thank $C$. Schäfer for versatile technical assistance. Financial support was granted by the Deutsche Forschungsgemeinschaft. 
Résumé - Variabilité génotypique intragroupe et comportement d'amassement chez l'abeille (Apis mellifica L.). Le comportement d'amassement de groupes d'ouvrières de composition génotypique variée a été testé au cours d'expériences utilisant des marqueurs génétiques (voir Fig. 1; le schéma de croisement). Les groupes étaient constitués de 60 ouvrières provenant d'une reine qui avait été inséminée par 4 mâles génétiquement différents. Outre les groupes d'ouvrières d'une même lignée paternelle, on a aussi testé des groupes mixtes de 2, 3 ou 4 lignées paternelles (Tableau I). La quantité (en g) de solution sucrée stockée et consommée en 8 jours et la concentration en sucre de la solution stockée ont été estimées (Tableaux II et III). Lorsque le nombre de lignées paternelles présentes dans les groupes augmente, la consommation de sucre croît (Fig. 1C), mais la quantité et la concentration de la solution sucrée stockée diminuent (Fig. 1a, b). C'est le premier cas où la variabilité génotypique d'un groupe exerce un fort effet négatif sur l'expression d'une caractéristique du groupe.

\section{Zusammenfassung - Genotypische In- tragruppenvariabilität und Eintragever- halten der Honigbiene (Apis mellifera} L.). In einem Experiment mit genetischen Markern (Kreuzungsschema siehe Abb. 1) wurde das Eintrageverhalten von Arbeiterinnengruppen mit verschiedener genotypischer Zusammensetzung getestet. Die Testgruppen bestanden aus 60 Arbeiterinnen einer Königin, die mit vier genetisch verschiedenen Drohnen besamt war. Neben Gruppen mit Arbeiterinnen einer Patrilinie wurden auch gemischte Gruppen aus 2, 3 oder 4 Patrilinien untersucht (Tab. I). Der innerhalb von 8 Tagen eingetragene und verbrauchte Zucker (g) und die Zukkerkonzentration der eingelagerten Zuk- kerlösung wurde bestimmt (Tab. II, III). Es zeigte sich, daß mit zunehmender Anzahl von Patrilinien in den Gruppen der Zuckerverbrauch anstieg (Abb. 1C) während die Menge und die Konzentration des eingelagerten Zuckers abnahm (Abb. 1a, b). Dies ist das erste Beispiel, in dem die genotypische Variabilität einer Gruppe einen stark negativen Effekt auf die Ausprägung eines Gruppenmerkmals hat.

\section{REFERENCES}

Adams J., Rothman E.D., Kerr W.E. \& Paulino Z.L. (1977) Estimation of the number of sex alleles and queen matings from diploid male frequencies in a population of Apis mellifera. $\mathrm{Ge}$ netics $86,583-596$

Brückner D. (1980) Hoarding behaviour and life span of inbred, non-inbred, and hybrid honeybees. J. Apic. Res. 19, 35-41

Calderone N.W. \& Page R.E. (1988) Genotypic variability in age polyethism and task specialization in the honey bee, Apis mellifera (Hymenoptera : Apidae). Behav. Ecol. Sociobiol. 22, 17-25

Crozier R.H. \& Page R.E. (1985) On being the right size : male contributions and multiple mating in social hymenoptera. Behav. Ecol. Sociobiol. $18,105-115$

Free J.B. \& Williams I.H. (1972) Hoarding by honeybees (Apis mellifera L.). Animal Behav. 20, 327-334

Frumhoff P.C. \& Baker J. (1988) A genetic component to division of labour within honey bee colonies. Nature (London) 333, 358-361

Hillesheim E., Koeniger N. \& Moritz R.F.A. (1988) Colony performance in honeybees (Apis mellifera capensis Esch.) depends on the ratio of subordinate and dominant workers. Behav. Ecol. Sociobiol. 24, 291-296

Kulincevic J.M. \& Rothenbuhler W.C. (1973) Laboratory and field measurements of hoarding behaviour in the honeybee. J. Apic. Res. 12, 179-182

Kulincevic J.M., Thompson V.C. \& Rothenbuhler W.C. (1974) Relationship between laboratory 
tests of hoarding behaviour and weight gained by honeybee colonies in the field. Am. Bee J. $114,93-94$

Lindaver M. (1952) Ein Beitrag zur Frage der Arbeitsteilung im Bienenstaat. $Z$. Vergl. Physiol. 34, 299-345

Milne C.P. (1980) Laboratory measurement of honey production in the honeybee. I. A model for hoarding behaviour by caged workers. $J$. Apic. Res. 19, 122-126

Moritz R.F.A. (1986) Estimating the genetic variance of group characters : social behaviour of honeybees (Apis mellifera L.) Theor. Appl. Genet. 72, 513-517

Moritz R.F.A. (1988a) Selection of group characters in honey bees (Apis mellifera). In : Africanized Honey Bees and Bee Mites. (Needham G.R., Page R.E., Delfinado-Baker, M. \& Bowman C.E. eds.) Ellis Horwood, Chichester, pp. 118-124

Moritz R.F.A. (1988b) Group relatedness and kin discrimination in honey bees Apis mellifera L. J. Anim. Behav. 36, $1334-1340$

Moritz R.F.A. \& Hillesheim E. (1985) Inheritance of dominance in honeybees (Apis mellifera capensis Esch.). Behav. Ecol. Sociobiol. 17, 87-89

Moritz R.F.A. \& Southwick E.E. (1987) Phenotype interactions in group behavior of honey bee workers (Apis mellifera L.). Behav. Ecol. Sociobiol. 21, 53-57

Rinderer T.E. (1981) Volatiles from empty comb increase hoarding by the honey bee. Animal. Behav. 29, 1275-1276
Rinderer T.E. \& Baxter J.R. (1980) Hoarding behaviour of the honey bee: effects of empty comb, comb color, and genotype. Environ. Entomol. 9, 104-105

Robinson G.E. \& Page R.E. (1988) Genetic determination of guarding and undertaking in honeybee colonies. Nature (London) 333, 356358

Rösch G.A. (1925) Untersuchungen über die Arbeitsteilung im Bienestaat. I. Teil : Die Tätigkeiten im normalen Bienenstaate und ihre Beziehungen zum Alter der Arbeitsbienen. $Z$. Vergl. Physiol. 2, 571-633

Rösch G.A. (1927) Über die Bautätigkeit im Bienenvolk und das Alter der Baubienen. $Z$. Vergl. Physiol. 6, 264-298

Rösch G.A. (1930) Untersuchungen über die Arbeitsteilung im Bienenstaat. II. Teil : Die Tätigkeiten der Arbeitsbienen unter experimentell veränderten Bedingungen. $Z$. Vergl. Physiol. $12,1-71$

Sakagami S.F. (1953) Arbeitsteilung der Arbeiterinnen in einem Zwergvolk, bestehend aus gieichaltrigen Volksgenossen. Beiträge zur Biologie des Bienenvolkes, Apis mellifera L., II. J. Fac. Sci. Hokkaido Univ. Ser. VI, Zool. 11, 343400

Trump R.F., Thompson V.C. \& Rothenbuhler W.C. (1964) Behaviour genetics of nest cleaning in honeybees: $V$. Effects of previous experience and composition of mixed colonies on response of disease-killed brood. J. Apic. Res. 3, 25-30

Winston M.L. \& Katz S.J. (1982) Foraging differences between cross-fostered honeybee workers (Apis mellifera) of European and Africanized races. Behav. Ecol. Sociobiol. 10, 125-129 